Accounting as gendering and gendered: a review of 25 years of critical accounting research on gender

Accepted for publication in Critical Perspectives on Accounting

Doi: 10.1016/j.cpa.2016.06.004

\author{
Kathryn Haynes \\ Hull University Business School \\ Hull University \\ Cottingham Road \\ Hull \\ HU6 7RX \\ k.haynes@hull.ac.uk
}




\title{
Accounting as gendering and gendered: a review of 25 years of critical accounting research on gender
}

\begin{abstract}
:
This paper gives a critical review of 25 years of critical accounting research on gender, addressing what we have learned to date and what are the most challenging areas to be investigated in the future. It considers accounting as a political construct implicated in perpetuating inequality, with reference to global gender challenges. Gendered histories of accounting and stories of individual struggles show barriers to entry being overcome; but challenges remain. Accounting acts as both a gendered and gendering institution in relation to career hierarchies, motherhood, work-life debates, and feminisation and segmentation, and interacts with gendered identity, embodiment and sexuality. The paper outlines the contribution of feminist theory to accounting research on gender and calls for further research on the interaction of gender relations with global capitalism.
\end{abstract}

Keywords: gender, transnational feminism, accounting profession 


\section{Accounting as gendering and gendered: a review of 25 years of critical accounting research on gender}

\section{Introduction}

The interaction of accounting and gender has been subject to debate for many decades (Hopwood, 1987), and certainly since the inception of the Critical Perspectives on Accounting Journal some 25 years ago, when the editors called for research on the extent to which accounting reinforces or sustains relationships between individuals and groups on gendered lines (Cooper and Tinker, 1990). Scholars have addressed, inter alia, the gendered functioning of the profession in the labour market; the historical progress of women in the profession and their career trajectories; the gendered nature of accounting itself; and subjected the profession and accounting rationalities to feminist critique.

This paper gives a critical review of 25 years of critical accounting research on gender, addressing what we have learned to date and what are the most challenging and promising areas to be investigated in the future. In 25 years much has changed and yet little has changed. Women have made strides in developing their presence in the accounting profession, yet inequalities remain. There may be some areas to celebrate, such as the greater inclusion of women in accounting, but at what cost? The need to address gender inequalities across both genders and in all parts of the world, developed and developing, means that the role of accounting and the profession in perpetuating inequalities on gendered lines and on a global scale remains a serious concern.

The paper proceeds as follows: in the next section I outline the conceptual positioning in relation to gender, criticality and the distinction between gender and feminism. Section 3 considers accounting as a political construct implicated in perpetuating inequality, with 
reference to global gender challenges. Section 4 addresses gendered histories of accounting in terms of barriers to entry, individual struggles, and in non-western contexts. Section 5 discusses accounting as both a gendered and gendering institution in terms of how it relates to career hierarchies, motherhood, work-life debates, and feminisation and segmentation. Section 6 evaluates accounting's interaction with identity, embodiment and sexuality, and the role of men in gender literature. Finally, I conclude with a discussion of gender and accounting going forward, outlining some essential lacks in the literature, and calling for the need for further feminist approaches to gender research.

\section{Conceptual positioning and scope of the paper}

Before reviewing the literature and making the case for the need for further research in gender and accounting, I first wish to establish some key concepts applied in this paper: the nature of gender; concepts of criticality; and relations between gender and feminism.

\subsection{Gender}

The concept of sex is largely essentialist relating to biological difference between male and female, whereas gender is widely accepted to be socially constructed and informed by socially and culturally informed conceptions of masculinity and femininity (Oakley, 1985). Biological essentialism itself is also subject to social norms and understandings, and is partially gendered, such that gender relations are the outcomes of socio-cultural and historic conditions and processes in which people interpret and recreate the social world (Alvesson and Due Billing, 1997). Gender is therefore the effect of social definitions and internalisations of the meaning of being a man or a woman (Haynes, 2013b). Despite the concept of gender relating to both men and women, much research on gender focuses on the position of women, as they as a group have historically been subjected to more discrimination and oppression than men under patriarchal conditions. This focus is replicated in the accounting and gender literature which 
tends to focus on the position of women in the accounting context for the understandable reason that women more than men have been more likely to be excluded or oppressed (Haynes, 2008a). However, there is a case to be made that there are gaps in the accounting literature relating to the gendered position of men, and that taking gender seriously means addressing masculinity and the role of men. In order to understand the interaction of accounting with women's lives we also need to understand men's. I will address the position of men in more detail later in this paper.

Much gender research in the accounting literature as well as other disciplines continues to reflect on a gender binary, between male and female, although there are clearly distinctions within and between categories of men and women. In the accounting context, this potential conflation of sex differences with gender identities and roles has been subject to resultant critique. For example, Gallhofer (1998) criticises research that uses the term 'woman' as if it were a universal and unitary category which results in the suggestion that concerns addressed and issues raised are of equal importance and relevance for all women, thereby resulting in a failure to address the differences between women themselves. Hammond (1997) critiques Nichols et als' (1997) exploration of the interpretation of sexual harassment in accounting firms for failing to explore how sexual harassment reflects broader social conditions, and, by assuming an a-theoretical neutral position, for assuming that women are the cause of such harassment. What is known as a 'gender-as-a-variable' approach to exploring differences and gender divisions between men and women, has been subjected to extensive critique, suggesting that while these studies may address issues of critical importance to women, they primarily have an interest in gender as an object of study rather than as part of the research methodology and theoretical framework, and do little to contest inequalities and difference (Haynes, 2008a). It is not the role of this paper to engage in further critique of gender-as-a-variable studies, but 
to review the critical accounting research in relation to gender; consequently the focus of the review will be on 'critical' studies.

\subsection{Criticality}

In this context I assert a personal view on the nature of critical accounting research on gender, aware that it may not resonate with all critical scholars or all gender scholars, but it has been applied in the approach to this paper. Although critical accounting research has a rich and long history (Broadbent, 2002, Gallhofer and Haslam, 1997), in this paper I define it broadly, going beyond the definition of critical theory as associated with the Frankfurt School, to encompass research which has an emancipatory intent and/or outcome. While some gender studies have a clear political motivation and grounding in particular theoretical positions such as feminism or Marxism (see, for example, Cooper, 2001, Cooper and Taylor, 2000, Hammond, 2003, Haynes, 2008a), others illuminate the power, or lack of power, of particular social groups without necessarily having a stated or overtly emancipatory intent. Nevertheless, the outcome of such studies may be to subvert existing knowledge and understandings of gendered social relations, enabling further critique. In any case, the nature of emancipation will differ in different social, political and geographical contexts.

"A critical approach to research production recognises that the choice of subject is located within political processes in which some people's lives and experiences are regarded as interesting and/or important enough to be researched but not others" (Haynes, 2008a p. 544).

Many papers also draw from a wide range of inter-disciplinary perspectives, reflecting an intent to resist the financial economics-based accounting research tradition (Parker and Guthrie, 2014) which perpetuates the status quo and hence inequalities. It is for these reasons that I have included a broad range of studies on gender and accounting which expose and illustrate 
inequality, some papers from the management discipline which are relevant to critical accounting, and some history papers which provide new insights into accounting's past, and hence its potential future.

"Critical analyses...seek to expose the interested nature of social practices, to identify the interests behind them and to illuminate the partiality of their consequences." (Hopwood, 1987 p. 66).

\subsection{Relations between Gender and Feminism}

As we will see in this paper there is a great deal of literature on the relation between gender and accounting. However, to what degree is this feminist in its orientation? If gender is the organisation and social construction of sexual difference, studies which explore this difference tend to address the relational position of men and women, or relations between different types of women and men themselves. A feminist approach takes a much more overtly politically feminist position informed by feminist theory and feminist methodology. Feminist theory encompasses many feminist traditions (Donovan, 2001), including socialist feminist, ecofeminist, radical feminist, Marxist feminist, liberal feminist, post-modern and others. Central facets of feminist research methodology include 'challenging objectivity and valuing subjectivity; recognising the links between ontology and epistemology, and between research process and product; developing non-exploitative relationships within the research; aiming to bring about change for women; valuing the personal and the private as worthy of study; and using reflexivity as a source of insight' (Haynes, 2008a p. 545).

In the accounting context, there are some early and explicitly feminist studies originating in special editions of major critical accounting journals (Accounting, Organizations and Society, 1987, vol. 12 (1); Accounting, Auditing and Accountability Journal, 1992, vol. 5 (3); 
Accounting, Organizations and Society, 1992, vol. 17 (3/4) and Critical Perspectives on Accounting, 1998, vol. 9 (3). Cooper (1992) draws from the much underutilised theories in accounting of Kristeva and Cixous to critique mainstream accounting research in its orientation towards nature; such a critique is all the more relevant in the contemporary context with accounting scholars grappling with the challenge of global warming and environmental degradation, in a context where feminist theory is rarely used but may have much to offer (Haynes and Murray, 2013). Gallhofer's (1992) response to Cooper's paper reminds us that feminism has emancipatory potential, but that feminists must avoid biological essentialism and remain conscious of the need to analyse and critique global capitalism. Again these insights are highly relevant to contemporary accounting scholars. Feminist research according to Gallhofer (1998) should challenge the current socio-political and economic order and offer a counter to prevalent Western ethnocentrism. Hammond and Oakes (1992) outline a range of theoretical feminist positions which still provides a useful overview of feminist theory and its application to accounting some 23 years later, even though new conceptualisations of feminist theory have since emerged. Shearer and Arrington (1993) discuss the relevance of Luce Irigary to accounting, using her feminist deconstruction of Freud and Lacan to analyse dominant notions of accounting's relation to value, subjectivity, intersubjectivity and sexuality, areas which are still rarely addressed yet provide fruitful subjects for further research.

What these early feminist papers have in common, then, is the use of wider social science research and feminist theory applied to accounting in the interests of the deconstruction of and emancipation from patriarchal relations, and the critique of accounting's role in perpetuating global capitalism. Given these aims, it is surprising therefore that feminist theory and approaches to research, as opposed to studies of gender inequality, have not been more prevalent in the intervening years in the accounting context. Broadbent and Kirkham (2008), 
in a special issue of Accounting, Auditing Accountability Journal vol. 21 (4) on gender and accounting decry this point asserting that feminist approaches enrich study of gender and accounting, and that gender is an element that should be embedded in research in accounting. Haynes (2008a) argues for a distinctly feminist approach to research, demonstrating where this might be applied and arguing that this provides an opportunity to radicalise the accounting agenda. Walker (2008) provides a powerful critique of accounting histories of women published during 1992-2008 as studies of women in accounting during the past rather than actually feminist, arguing that this emphasis contributes to the recovery of women in accounting history by revealing the gendered character of professionalisation, documenting hidden female experiences and uncovering the foundations of exclusion, but does not constitute or advance an explicitly feminist account. Some later historical studies emphasise in the sustained nature of the campaign for the inclusion of women in the profession an alignment with contemporary feminism (Walker, 2011b). In the opposite vein, Jeacle (2006) explicitly refutes the established feminist critique of cosmetic use by women in the western world when positioned against accounting evidence of the history of consumption.

In what has become known as a post-feminist era, in which feminist gains of the 1970s and 80s in the western context came to be undermined and undone by pernicious elements of contemporary popular culture while simultaneously appearing to be engaging in a wellinformed and even well-intended response to feminism (McRobbie, 2004, 2009), the role of feminist critique for accounting may appear less relevant. In an age of post-feminism, Broadbent and Kirkham (2008 p. 466) reflect that feminist issues, according to some critics, have been side-lined or trivialised as "political correctness". Moreover, faced with hostility and scepticism from some academic audiences, Dambrin and Lambert (2012) reflexively describe how their intent to transform the structures of domination has led them to alter their approach 
to feminist and gender discourses in different contexts, enabling them to convince reluctant audiences by adopting a pragmatic presentation style. The influence of post-feminism on accounting research is an area which remains largely unexplored. Nonetheless, a critique of post-feminism can direct critical attention to the kinds of organizational subjects women (and men) are being asked to become in a post-feminist climate where women's belief that they are equal means that ongoing sources of inequality are ignored, rendered invisible and have become increasingly difficult to name (Lewis, 2014).

Despite a societal backlash against feminism in popular culture (McRobbie, 2009), the potential influence of feminist theory in accounting widens the scope of inequalities being addressed, by bringing in a wider range of marginalised voices including those of minority groups and women in the developing world (Cooper, 2001, Hammond and Oakes, 1992, Lehman, 2012). Feminist theory also allows for new ways of evoking change (Dillard and Reynolds, 2008) and educating for sustainable development (Haynes and Murray, 2015). In her powerful review of pioneering feminist research in various disciplines, Lehman (2012) argues for its role in moving feminist accounting research forward in advancing sexual rights, promoting action, challenging racism, classism, sexism, ageism, and evolving social justice, necessitating openness in our ways of imagining and relating to each other, and providing a 'foundation for new insights and enhanced possibilities for advancing and transforming the field' (Lehman, 2012, p. 256). Lehman (2012) suggests that innovative multidisciplinary works from different regions of the globe reveal methods for challenging entrenched premises of gender and recasting new meanings, in order to open up the margins and boundaries of gender and accounting research. There is therefore a strong case for continued feminist research in accounting (of which more later in this paper), not least due to the issues raised relating to women and girls in the next section. 


\section{Accounting as a political construct implicated in inequality}

Unequal distribution of power, property and wealth is inherent in modern capitalist societies and much inequality is structured along gendered lines. Although poverty, for example, affects the world's poor irrespective of gender, and despite the 'feminization of poverty' thesis being contested in its calculations (Chant, 2006), there is evidence that around the world women and girls bear the brunt of challenges arising from economic, social and environmental development, through the feminisation of poverty, disease, and hunger; the burden of unpaid work; adverse health and impacts from environmental degradation; vulnerability to conflicts and violence; lack of food security and land security; water and sanitisation issues; lack of political representation; and lack of education (United Nations Department of Economic and Social Affairs, 2010). Progress in achieving gender equality in addressing United Nation's Millennium Development Goals on hunger, education, political representation, and health remains problematic and disproportionately affects women (United Nations, 2012).

Accounting is implicated in perpetuating this inequality. Accounting has long been associated with supporting market capitalism and shareholder value (Bryer, 2000, Catchpowle, Cooper and Wright, 2004, Chiapello, 2007), imbued in the late $20^{\text {th }}$ century with neo-liberalist concepts of de-regulation, market power and privatisation (Morales, Gendron and Guénin-Paracini, 2014). Decreasing power of organised labour, the dismantling of the welfare state, and a focus on individual achievement and responsibility rather than redistributive justice is the focus of much of the politics of the global north. The pursuit of economic growth, intensified since the financial crisis, raises serious questions about the ability of the world to achieve a more sustainable future and stave off the effects of climate change. Since climate change is now 'unequivocally' linked to human industrialised activity (IPCC, 2007, 2013), the role of 
organisations and business in solving or perpetuating the problem becomes more significant. Moreover, as with poverty, there are claims that the effects of climate change will disproportionally affect women more than men. For example, in continents such as Africa women's traditional roles as the primary users and managers of natural resources, primary caregivers, and labourers engaged in unpaid labour, mean they are involved in, and dependent on, livelihoods and resources that are put most at risk by climate change while simultaneously they are less likely to be involved in decision-making about solutions (United Nations Economic Commission for Africa, 2009).

These varied challenges facing women and men are inter-related with organisations and markets, and hence with accounting, as accounting processes, decisions and reports inform and support organisational decision-making, strategy and financing. Improvements in communications, IT, and accounting systems, together with the expansion and, most significantly, the deregulation of capital markets, have led companies to consider new ways of structuring their activities, often by taking their manufacturing base to developing countries to make the most efficient use of low taxes, advantageous inward investment opportunities, and cheap labour, often involving the sweatshop labour of the world's poorest women. Neoliberalism shapes the relationship between markets and politics, and accounting as a tool of neo-liberalism is implicated in a host of practices which have gendered effects:

"The pursuit of profit, for a minority, affects accounting and financial practices in relation to division of labour, provision of capital, production of goods and services, identity politics, work within and without the home, maintenance of households and childcare, for the majority" (Haynes, 2008a p. 540). 
The global accounting profession also has a role in maintaining neo-liberal ideologies, not only in advising upon and regulating accounting and reporting systems, but also in relation to gender equality, politics and policies, reflecting the influx of women into the profession in recent decades. This raises questions about the representation of women in the profession, career opportunities and progression, and the degree to which the profession reflects the shifting gender demographics of society or actively shapes that society.

This discussion of accounting as a political construct implicated in causing and perpetuating gender inequalities sets the scene for the review that follows and my argument for the need for further research on the interaction of gender and accounting. These challenges epitomise the real and significant problems experienced by women, and men, differently and collectively, in both the global south and the global north. They resonate with Lehman's (2012, p. 256) call to tie 'the current rhetoric of global neo-liberalism to contemporary feminist struggles [to]...illustrate the significant consequences of economic globalization on women, and accounting's connection'. They also represent why research on gender and accounting should not be experienced as a marginal, minority pursuit, as recounted powerfully by Dambrin and Lambert (2012), but should be central to the concerns of critical accounting scholars in the interests of emancipation and social justice.

\section{Gendered histories of accounting}

\subsection{Barriers to entry}

Understanding some of the gendered history of accounting enables us to trace the social and cultural norms which have shaped its progress. While the accounting profession is made up of many self-regulatory professional bodies around the globe, there are some commonalities between them. Entry to professions is limited by professional closure, referring to the way that 
membership is limited to those who meet stringent entry requirements, to defend their collective interest from outsiders (Haynes, 2013a, Larson, 1977, MacDonald, 1995). These outsiders historically included women as well as the lower educated and working class. Much of the early literature on the entry of women to the accounting profession focuses on the AngloSaxon US/UK context, where the early development of the formalised professions occurred, and I first address this context before later in this section addressing the gender challenges relating to the inclusion of women elsewhere in a non-Western or developing world context.

Admission to the accounting profession for women occurred over many decades of struggle. As Lehman (1992) points out in her ground-breaking paper on the herstory of accounting over an 80-year period, gender conflicts restricting women's access to the profession have persisted since the early 1900s. Kirkham's (1992) commentary on Lehman's paper adds a further political dimension by analysing women's oppression within accountancy in terms of its interrelationship with the development of the profession itself, examining power and influence in the profession and the constitution of its knowledge base in terms of gender. In other words, accounting was conceptualised from the outset as a masculine practice, and the profession reflected this through the application of closure regimes 'through which theoretically inexhaustible knowledge resources become socially finite' (Larson, 1977 p. 223). Until the latter half of the twentieth century, the professional echelons of accounting were a male preserve (Westcott and Seiler, 1986) and the masculine qualities required 'contrasted markedly with the image of the weak, dependent, emotional "married" woman of mid-Victorian Britain" (Kirkham and Loft, 1993 p. 516). As they entered the profession women were confined to book-keeping and clerical functions (Kirkham and Loft, 1993) in late $19^{\text {th }}$ century Britain, in which, as Walker (2003a) demonstrates, they practiced accounting on the border of public and private domains such as in family businesses, hotels and retailing. This, he argues, reflects the 
growth of women in the labour market as a source of cheap labour, and the growth of liberal feminism which construed such work as suitable for women. Stratification of the accounting labour market along gendered lines may still be seen today and is discussed later in this paper. The experience of the majority of women in the early twentieth century was of legal, socioeconomic, constitutional, and cultural opposition to their membership of the profession in the UK and US (Kirkham and Loft, 1993, Shackleton, 1999, Wootton and Kemmerer, 1996). Moreover, Walker (2003b) finds that during the early twentieth century in the USA and UK, the interaction of accounting with the ideology of domesticity, founded on precepts derived from scientific management and household engineering, attempted to occupy middle class women in the domestic sphere, reasserting private patriarchy and diverting attention from career, rather than offering a source of professionalisation and liberation.

This resistance to the inclusion of women in the professionalisation of accounting became an issue of rights between men and women. Cooper K. (2010), for example, traces the campaign by women in Australia in the late nineteenth and early twentieth centuries to gain admission to accounting bodies, in a context where women were perceived as having neither the nature nor the intelligence for the commercial world and where many men feared that their rights would be compromised if women had equal rights to compete in the workforce. During the late nineteenth and early twentieth century in England and Wales, Walker (2011b) finds that the campaign for admission of women comprised a usurpationary struggle pursued in civil society, where equal rights were emphasised and credentialist tactics deployed. These efforts were successfully resisted by the professional elite, and when, in consequence of male demands for a statutory monopoly, the issue entered the state arena and legalistic tactics were pursued, the admission of women was conceded in principle, but the subsequent emergence of separatist 
solutions offered scope for internal demarcation and the creation of a gendered hierarchy within the profession under patriarchal control (Walker, 2011b).

\subsection{Individual struggles}

To illustrate the considerable trials that some women had to face in gaining admission to the profession, a number of authors have traced the personal histories of high profile or pioneer women in accounting. Some, such as Mary Addison Hamilton, are excluded from formal recorded histories of the accounting profession despite being one of the first women to achieve membership of one of Australia's recognized professional accounting bodies and achieving a permanent position in the public sector at a time when Australian women were traditionally denied such positions (Cooper, 2008). Similarly, Jeacle (2011) examines the career of one of Scotland's first female chartered accountants, Helen Lowe, who established her own accounting practice in 1928, suggesting that female gender, often viewed as a negative characteristic to achieving career success within the discriminatory environment of the accounting firm, may act as a positive attribute in business more generally.

These stories are important in illustrating individual experience within the broader sweeping history of the western early twentieth century gender struggle in the accounting profession (Jeacle, 2011) and celebrate the achievements of individual women accounting pioneers, often absent from 'malestream' histories. Moreover, while it is important to acknowledge the sometimes ignored role of women practitioners in accounting history, some histories can also address the political and emancipatory influence of accounting as a tool utilised by women, not only for their own personal career, but also in the services of other women and wider society. In this regard, Walker's (2011a) account of the life of Ethel Ayres Purdie, a female certified accountant and militant suffragist, illustrates how the professional services which women 
accountants offered to feminist organisations represented an important contribution to the suffrage movement in late nineteenth, early twentieth century Britain.

However, despite being historically excluded from the profession for apparently lacking the requisite skills or what are termed forms of capital, the essential need for women's labour due to a shortage of male accountants during World War II led to women being employed in these otherwise male-dominated positions, giving women the opportunity to challenge the general belief that they were unsuited to accounting work (Ikin, Johns and Hayes, 2012). In the later twentieth century, women's participation in the accounting profession, in both the United Kingdom and the United States, increased as women surmounted the barriers to entry (Ciancanelli, Gallhofer, Humphrey and Kirkham, 1990, Wootton and Kemmerer, 2000). However, this changing gender balance has not been straightforward. Ciancanelli et al.'s (1990) analysis of the state of the accounting profession in the UK in 1988, showed that quantitative changes in the numbers of women were not accompanied by gender transformation in the profession's hierarchy. Such concerns about the position of women in the accounting hierarchy remain in the contemporary period (Dambrin and Lambert, 2012, Haynes, 2013a); of which more below.

\subsection{Histories in Non Anglo-Saxon and non-democratic contexts}

Despite the commonalities noted above in relation to much of the experience of women in professions, especially in the large professional services firms which are relatively homogenous, the geographical, political and cultural context also needs to be addressed to provide insights into areas of difference. Carrera et al's (2001) study of the role of gender in Spanish audit practice during the period 1942 to 1988 finds that the audit profession mimicked the attitudes deployed by the state during a transition from dictatorship to democracy, noting 
that the wider contexts of the profession are characterized by political and economic regimes which are significantly different from the liberal democracies and free market economies that identify many Anglo-Saxon countries. Although promotion to partner processes in the Big 4 across the western contexts of Canada, Spain, France and the UK remain relatively homogenous in privileging the acquisition of economic capital, there is heterogeneity in the way that this may be achieved (Spence, Dambrin, Carter, Husillos and Archel, 2015).

Moreover, there is a dearth of critical accounting literature on the more distant histories of women in accounting in non-western contexts. One exception is Komori's (2007) study of the changing relationship between women and accounting in Japan across five historical periods, which reveals that accounting has been an instrument of the state in the social construction of gendered roles and women's position in Japanese society, to which women have proactively responded, using their accounting role to help enhance their political power as consumers, and using it as a way for them to build on their feminine identity. Komori (2008) also finds that women accounting professionals have brought about changes in accounting practice by applying a uniquely feminine approach in their day-to-day work, which is attuned to the ongoing globalization in the field of accountancy, helping to widen the opportunities for women in Japan.

In other non-western contexts, the lack of earlier history of women in accounting is partly because the entrance of women to the formalised profession is occurring in more recent times, thus studies reflect the more contemporary position. History of women's participation in accounting continues to be made now. For example, in a ground breaking study of Saudi Arabia, Alsalloom (2015) finds that women themselves have a 'desire for change' through assimilation into the profession, but meaning and action for change towards gender equality is 
conceptualised differently being interpreted through culture, sociocultural values and selective interpretation of religion. Alsalloom's (2015) interpretation is mediated through a feminist lens applied to the particular patriarchal conditions specific to that context, rather than "the culture of one particular group of women, namely white Western middle-class women" (Gallhofer, 1998 p. 366). Komori (2015) similarly draws attention to the Anglo-centrism of accounting research in the international arena. Kamla's (2012) study, which precedes the recent wars in the region, explores the tensions inherent in globalization in Syria and how it impacts on the experiences of Syrian women accountants, calling for research that addresses conditions contributing to Syrian women's marginalization in the accounting and finance professions, and beyond. Other work, as yet unpublished, is beginning to emerge on the contemporary history of women in accounting in other non-western contexts, for example, Brazil and Thailand. We as yet know little about the developing state of gender relations in accounting in areas such as Africa and Asia. Similarly, apart from Lee Cooke and Xiao's (2014) study of auditors' career aspirations in China which finds that gendered differences are informed by social conventions of gender role, organizational practices, and personal preferences, there is little information about gender and accounting in China, with its differing political relations and histories between individual, work and state. There is a great opportunity for more scholars to address the diverse global experiences of accountants in relation to gender to enrich our understanding of the relationship between socio-cultural, economic, political and global context. There is also an increasing opportunity to apply feminist perspectives relevant and relative to that specific global context, acknowledging that accounting is both a gendered and a gendering institution.

\section{Accounting as a gendered and gendering institution}


When considering accounting as both a gendered and a gendering institution, there are two issues at play: first, the role and conduct of the accounting profession in reflecting the wider norms of the societies in which it operates; and secondly, the profession's role in shaping and influencing those societal norms, as well as the positions and practices of the professionals who work for and in the profession. The two are also mutually inter-related. As Hines (1988) noted many decades ago, but which still continues to be relevant: accounting both reflects and shapes reality. This applies to the conduct of the profession as well as accounting practice. Moreover, the 'accounting logic' which underpins the practice of accounting has been argued by Broadbent (1998) to be gendered, by representing the value set of the 'universal masculine'. While, in contrast, anything representing the 'universal feminine' might be said to be contentious since femininity and masculinity do not necessarily represent binary constructs, as discussed in section 2.1, Broadbent's (1998) paper raises important and relevant issues about the gendered and singular nature of the values embedded in the 'accounting logic' underpinning conventional accounting, which exclude multiple or alternative value sets .

As previously discussed, the early experience of women in accountancy was of surmounting barriers to entry in a patriarchal context (Kirkham, 1992, Lehman, 1992), where women were associated with clerical work (Kirkham and Loft, 1993) and excluded from accounting knowledge (Crompton, 1987). Loft's (1992) review essay demonstrates how accounting reflects the wider societal norms of an era where women are more likely to be employed in clerical than professional work. When we fast-forward 25-30 years to the contemporary profession, the position is that accounting as a historically masculine profession has opened its doors to women in large numbers but many challenges remain involving gendered career hierarchies; interaction with motherhood; work-life issues and choices, and feminisation and segmentation in the profession. 


\subsection{Gendered career hierarchies}

Despite the influx of women, the professional hierarchies of accounting remain resolutely gendered, with a preponderance of men at senior levels, despite the efforts of the accounting firms to target policies towards supporting women (Broadbent and Kirkham, 2008). Dambrin and Lambert's (2012) review of the lack of women in the higher echelons of accounting suggests that until stereotypes are challenged gender inequality will remain. They link the need to perform critical and reflective research on gender with an ongoing struggle to improve the position of women's representation in the accounting profession.

Given the masculine history of the profession, stereotypes may be difficult to shift; one rationale for this being male organisational homo-sociality in the profession, or the tendency for male partners to recruit those from similar backgrounds to themselves (Anderson-Gough, Grey and Robson, 2005, Kanter, 1977). In addition, the evaluation of career promotion opportunities involves not only technical and perceived managerial skills of leadership and team-working, but also integration into norms of temporal commitment and a firm-approved social life, which erodes the boundaries between firm and private time that systematically disadvantages female auditors with family commitments (Anderson-Gough et al., 2005). Therefore, as Anderson-Gough et al (2005) point out, research on gendering processes in the accounting profession necessarily combines consideration of both the formal mechanisms of organizational structuration, such as recruitment, appraisal and training, and the informal processes in terms of cultural norms, values and beliefs that play through how the formal processes are enacted and reproduced. 
Career advancement necessitates self-management to demonstrate individual contribution and the need to 'fit' a prevailing model of success within the firm which is arguably a masculine model and hence more problematic for women (Kumra and Vinnicombe, 2008). In addition, the need to develop strong social networks for career advancement is well-established in professional services firms (Anderson-Gough et al., 2005, Grey, 1998). Various strategies are utilised to achieve this development of social networks and social capital. Kokot's (2014) comparative study of Germany and UK finds that in Germany, career advancement is often negotiated through personal relationships of trust in smaller firms and professional relationships that are maintained largely in the public sphere in larger firms, whereas in the UK, head-hunters and recruitment agents are an important tool used by women to navigate their careers because such agents can more neutrally point out the skills of women and disrupt homo-sociality. Kumra and Vinnicombe (2010 p. 521) argue career success necessitates the use of impression management to ensure one is always perceived as 'ambitious, likable and available'; these are key organisational norms that women need to actively accumulate to dispel the negative stereotypes of lack of ambition and unavailability for long hours of work that attach to them because of their gender. In a similar vein, Mueller, Carter and Ross-Smith (2010) find that women's career advancement in Big 4 accounting firms is shaped by their real and perceived willingness to be 'bothered to be playing the game' in addition to providing a good client service and participating in the ongoing rationalization of professional practices. They go further to examine the effects on women in the performance of gender, finding that on the one hand women have to be perceived as ambitious, committed and loyal to the firm and to the notion of performing, whereas on the other they experience distancing and disenchantment with existing organisational practices and the reluctant acknowledgement that reality is characterized by a culture of visibility and exposure; the need to network, play politics and be playing-the-game, none of which are gender-neutral. The performance of gender in a 
constrained environment such as accounting causes considerable tensions in identity formation and execution (Haynes, 2006, 2008c, 2011).

While most of the literature on career progression in accounting is related to larger firms, especially what is now the Big 4, Adapa, Rindfleish and Sheridan (2015) provide a welcome insight into women's absence from senior roles in small and medium sized accounting firms in regional Australia, where unlike large accounting firms, small and medium sized regional firms are not required by Australian legislation to address women's disadvantage. Adapa et al (2015) find that the internalization of gender stereotypical beliefs about what women can do intersects with the 'tradition' of regional and small to medium size of the accounting firms in the study to entrench a specific type of disadvantage for women, where women were both the subject of gendered stereotyping but also imposed limitations on themselves when considering career. Such research outlines the importance of understanding normative processes and practices affecting gender at the intersection of the societal, professional organisational and regional context; an intersection which has not been explored in full and represents an area for further research on gendering.

\subsection{Motherhood}

Motherhood and its interaction with the accounting profession demonstrates an area of social life where private, domestic and personal lived experience intersect with professional, publicfacing working life (Haynes, 2008c). It is an example of where women are subjected to gendered and gendering processes in both accounting and wider society. They face the societal and cultural norms associated with mothering, and the stereotypical assumptions surrounding mothers in firms; leading to difficult personal choices in relation to working life and juxtapositions between personal and professional identities (Haynes, 2008c). Although 
parenting is acknowledged to be a joint responsibility, mothers retain the primary caregiving role in most countries and economies. Whiting and Wright (2001) find that while the New Zealand accounting profession has a scarcity of female personnel in the top echelons, it accommodates working mothers to a larger extent than in Ireland, but requires mothers to undertake a balancing act between career and family responsibilities that often takes the form of part-time working, whereas male accountants work longer hours and suffer less discrimination. In France, auditor mothers are faced with societal and organisational expectations which conflict, leading to their being excluded or excluding themselves from the group "who may become partners" (Dambrin and Lambert, 2008). As a result, women who try to manage the dilemmas caused by motherhood attempt to shape their working practices by implementing tactics to adapt their work-life balance, through specialisation or moving into staff positions, leading to individual trajectories that do not conform to the organisational model and thus account for the scarcity of women in the upper management levels in audit firms (Dambrin and Lambert, 2008). It is hard to separate motherhood from other aspects of career advancement (or limitation), as it is clearly intertwined with society's expectations of mothers, particularly working mothers, in terms of stereotyped ability to commit to work and the organisation, and the ability to work the required hours. This leads to tensions and choices in managing the interface between 'work' and 'life', as it they are two separate spaces and relations; whereas they are incommensurably intertwined in modern family life and organisation.

\subsection{Work-life balance, choices and flexible working}

Work-life constraints, choices and difficulties occur in many working contexts, for both women and men, but in accounting they are exacerbated by the requirement for long-working hours reflecting perceived levels of commitment (Anderson-Gough et al., 2005). Ladva and 
Andrew's (2014) study of young accounting professionals finds that time budgeting controls and the dominant discourses of "efficiency" and "career" form a web of control within accounting firms that sustain this long-hours culture; using a Foucauldian analysis, they argue that this web of control is not imposed externally by a clearly identifiable source of power, but is actively produced by junior accountants to secure their identity. Career progression to manager requires the destabilisation of previous identities and the taking on of new practices shaping the identity of managers in the Big 4 (Kornberger, Justesen and Mouritsen, 2011). It is not surprising, then, that when accountants become mothers their identities go through further transition and transformation, as they negotiate their identity roles (Haynes, 2008c), and some of them will decide to work part-time or opt for flexible working. Windsor and Auyeung's (2006) study of career progression in Australia and Singapore finds that dependent children significantly affects the management advancement of mothers, whereas the careers of fathers advance more quickly than their female counterparts, causing the authors to conclude that international accounting firms should have formal policies such as flexible working arrangements and appropriate job designs to encourage more mothers into senior management.

However, the consequences of flexible or part-time working are contested. Gammie and Whiting (2013) suggest that the primary reason women leave professional accountancy firms is to seek more interesting work as opposed to obtaining more flexibility in their working lives, whereas Dambrin and Lambert (2008 p. 502) conclude that audit firms will not jeopardise the business model by proposing true flexibility to parents, and by failing to allow flexible working 'suffer from resource wastage because they cannot, or will not manage flexibility'. Part-time work in accounting is perceived as career limiting despite the fact that when accountants work part-time they are likely to work longer hours than contracted (Crompton and Lyonette, 2011). Moreover, Kornberger, Carter and Ross-Smith's (2010) study finds that when Big 4 firms 
initiate flexible working policies with the intended aim of enhancing the progression and retention of professional women at senior levels, the practice is subverted and undermined by three issues: the redefinition of flexibility to mean serving clients flexibly rather than organising family life flexibly; the link between visibility and perceived increased work performance; and the notion that flexibility caused an inability to service large client's needs adequately. Such flexible working perceptions also act as a gendering process (Kornberger et al. 2010) as it is women, the object of the policies they are designed to support, who are more likely to be affected negatively by their implementation. The myth of 'choice' in flexible working patterns is exposed as a construct which is subjected to organisational constraints. It is also subjected to societal norms and constraints, as although workplace-related barriers still hinder mothers' career progression in accountancy, the division of domestic labour is at least, if not more, important (Lyonette and Crompton, 2008).

Kokot's (2015) study of perceptions of sexism and opportunities for women accountants in the UK and Germany identifies some interesting differences between their experiences and expands on this notion of 'choice' from a cross-cultural perspective. She finds that in Germany the accountancy profession is represented as an egalitarian space, despite evidence of sexism, where women make an individual 'choice' about their career drawing on narratives of 'strength'; whereas in the UK, women were more likely to admit experiencing and challenging sexism at work and perceive continuing structural constraints (Kokot, 2015). Moreover the notion of choice itself, drawing from Hakim's contested notion of preference theory, which distinguishes between work-centred and home-centred women, has been subjected to some critique in the accounting context. Women in professional services firms do not feel that they have genuine and unconstrained choice over their career advancement and suffer disparity in relation to men, due to a number of structural constraints such as masculine models of success 
(Kumra, 2010). In contrast, Gallhofer et al (2011) find more merit in the application of preference theory to accounting suggesting that women are less subject to structural constraints (such as the ability to work part-time or not) and are more likely to exercise what they see as a relevant preference in their work-life-style choices, although they acknowledge this only occurs when they are able to exercise this choice in the context of being middle class women in affluent modern societies.

\subsection{Feminisation and segmentation}

We have seen how accounting reflects some of the tensions inherent in global societies in terms of gendered roles. However, the accounting profession also shapes society. As a major institution with powerful global players, in the form of major global firms, it has a powerful role to play in normalising what gender roles are played out and developed over time. Back in 1992, Roberts and Coutts (1992) asked to what degree women will be marginalised as the accounting profession is feminised, as the profession struggled to consolidate its privileged position in capitalist society. They argued then that since the position of women in society is a subordinate one, the increasing feminisation of accounting may adversely affect this struggle and as a result, complex patriarchal structures evolve to reduce the threat to professionalisation that feminisation may pose, and also to reduce the contradictions between women's subordinate role in society, and their relatively privileged role in professionally aspiring occupations (Roberts and Coutts, 1992). More recent research provides insights into contemporary feminisation processes.

As feminisation has continued apace, professions have become segmented along increasingly gendered lines (Bolton and Muzio, 2008). For example, in the legal profession Bolton and Muzio (2007) find that gendered segmentation, which thrives on the ideology of women's 
difference, ensures that the elite masculine segments hold onto their status and associated rewards while the feminised segments increase leverage without rocking the partnership system, effectively forming a reserve army of legal labour with lesser terms and conditions. In the accounting profession, similar trends are evident. Almer, et al. (2012) identify the emergence of alternative career structures, observing such roles are typically undertaken by women and expressing concern they may lead to 'pink ghettos' and a new form of vertical segregation. Similarly, Khalifa (2013) finds that gender is an encompassing conceptual frame for ordering discursive attributes of the different specialisms within accounting and Lupu (2012) suggests the construction of alternative, feminized routes rather than 'approved' traditional routes, in the French 'Big 4' accounting firms, derails women's careers from a very early stage. Referring to the Japanese context, Komori (2008) suggests that the feminisation of accounting practice in Japan has helped to enhance the significance of auditors in Japan, and the role and position of women in the Japanese accounting profession in its move towards globalisation of the field. In contrast, referring more broadly to women's employment in Japan, Nemoto (2013) finds that pervasive vertical segregation on gendered lines, concentrating women's participation in lower level or less prestigious positions in Japan, supports the legitimation of masculine organizational cultures that stereotype women. Hence, as Joyce and Walker (2015) find, advances towards egalitarianism in the numbers of women in the profession are offset by processes of occupational segmentation and feminisation, which is pervaded by gender essentialism, indicating the "continuing potency of gender in everyday professional life, the limitations of diversity-orientated policies and the complexities of formulating transformative agendas' (Joyce and Walker, 2015 p. 41).

These studies of career, motherhood, work-life choices and segmentation reflect the fact that research on gender inequalities in accounting needs to take account of the context in which 
they take place. The profession reflects some wider societal norms about the role and position of women and men in society; but it also shapes and influences that society through the employment of large numbers of professionals in increasingly powerful global firms. Women's career and work-lifestyle choices are limited by structural constraints, both organisational and societal. In a post-feminist climate, where there is a pervasive belief that equalities have been met and feminism is no longer relevant (McRobbie, 2004, 2009), especially amongst young professionals (Kelan, 2014), there is all the more need to explore the subtle inequalities inherent in global employment practices, where despite the recognition that in some cases individual needs may be met, structural issues remain. For example, women may exercise 'choice' in flexible or part-time working, especially related temporally to raising children, but if they want to return to full-time work or progress their career they are still subjected to stereotyping, gender pay gaps, gendered hierarchies, and discrimination. A more politically informed feminist perspective is therefore still relevant to identify and understand gendered power relations in accounting, and also to understand where 'choice' is constituted by social relations. It is also important to relate the institutions of accounting to other societal and cultural regimes such as the economy, where employment patterns have become more precarious, and family, whereby traditional heterosexual, two-parent, permanent family structures have shifted in significance.

\section{Identities, Bodies and Sexualities intersecting with gender}

The organisation of professional and family life relies on concepts of masculinity and femininity and the performance or doing of gender and sexuality. Yet these areas remain under researched in accounting. There is a need to understand further the interaction of accounting systems and professions in capitalist economies as a normalising tool interacting with identities, embodiment, sexualities and emotions. 


\subsection{Identity and intersectionality}

A stream of work addresses professional identity in accounting (see, for example, Gendron and Spira, 2010, Hamilton, 2013, Jeacle, 2007, Kosmala and Herrbach, 2006, Morales and Lambert, 2013) and its interaction with personal identities which are gendered (Haynes, 2006, 2008c, 2012). However, gendered identities do not exist in isolation; rather they intersect with other identities involving race, age, class, able-bodiedness or disability, or other categories. Research on intersectionality fulfils the important function of highlighting how intersecting identity categories shape the experience of individuals (Kelan, 2014), often causing them to experience multiple forms of marginalisation or oppression. The concept of intersectionality has been widely explored in organisation studies (Holvino, 2010), while in accounting, it has been largely absent as an explicit concept despite some papers addressing the marginalising effects of intersectional identity. One exception in this vein is Hammond's (2003 p. 9) review of historical research addressing gender, race and class, in which she calls for more 'explicitly political motivations for historical accounting research and an ever-present focus on how this research can help ameliorate current oppressive conditions in which accounting plays a role'. In other words, critical accounting research is concerned with not only exploring, but improving, the lives and opportunities of those marginalised by accounting's power in society. Other scholars have addressed race, ethnicity and accounting (Annisette, 2003, Hammond, 2002, Hammond and Streeter, 1994, Viator, 2001); the interaction of race and gender (Fearfull and Kamenou, 2006, Robinson-Backman and Weisenfeld, 2001), and the role and intersection of race and with political constructs such as neo-liberalism or imperialism (Annisette, 2000, Kim, 2004, McNicholas, Humphries and Gallhofer, 2004). These papers reflect only snapshot of research in this field, because it is beyond the scope of this paper to consider race and accounting in detail as it is covered elsewhere (reference to another paper in the special issue?). 
However, the important point to note is that understanding the intersection of gendered identities with other identities brings richness and a more nuanced understanding of the politics of identity in accounting. The same might be said for other identity categories involving class (Jacobs, 2003) and disability (Duff, 2011, Duff and Ferguson, 2011a, b). However, to date, intersectionality within accounting has not been fully explored and represents a ripe area for further research, especially addressing issues rarely addressed, such as religion, age and sexuality.

\subsection{Embodiment}

Embodiment refers to the perception that one's body represents, or embodies, a particular form of identity. While bodies have a biological dimension, they are also widely acknowledged in the sociology of the body literature as being socially constructed in the sense that they are imbued with social and cultural norms of the context in which they are found (see, for example, Cregan, 2006, Shilling, 1993, Turner, 1996). Bodies are also gendered, raced, classed, aged, abled or disabled; hence they are at the core of intersections of identity.

Yet in the accounting context the body has only exceptionally been addressed. Jeacle (2003) provides an interesting insight into how accounting techniques encouraged the pursuit of a standardized measurement system which lies at the core of twenty first century perceptions of the human body, demonstrating how accounting acting as a vehicle for self-monitoring, mobilises forces which shape and reshape broader social practices. The pursuit of a perceived requisite body image in modern society, and accounting's function in that commodification, is an area which further research could usefully address, where a gendered or other intersectional angle is clearly relevant. 
Some scholars have addressed the issue of physical appearance in the accounting profession and its interaction with gender, especially in relation to the images used by companies in annual reports (Benschop and Meihuizen, 2002, Bernadi, Bean and Weippert, 2002, 2005) and by the profession itself. Images used in the Big 4's annual reports suggest that the job functions and locations in which people are portrayed evidences stereotyping and inequality (Duff, 2011). Edgley, Sharma and Anderson-Gough's (2015) study of images of gender and race diversity emerging in the Big 4's social media spaces in the UK, US and Canada finds that diversity has been institutionalised through attachment to traditional, commercial, professional discourses and motifs, but does little to indicate a rupture in the power of firm hegemony. Kyriacou's (2015) analysis of the images utilised by the Greek Accounting Professional Institute finds a proliferation of images of men and a lack of images representing professional accounting women, which reflects the dominant male structures of the profession and contributes to the reproduction of diachronically established power relations, gender inequalities and gendered hierarchies. What these studies reflect is the apparent recognition of the profession of the need to address equality and diversity more appropriately, and engage with the business case of a more diverse workforce, but the inability to enact this by ensuring that women are not positioned as marginal and somehow 'other' or outside the professional norms of accounting. This is yet another example of how the accounting profession not only reflects a social construction of reality but actively reproduces that cultural construction.

Very few studies have addressed embodiment as it is experienced within the professional accounting firm. In relation to appearance, attire and the wearing of the hijab, Kamla (2012) reveals tensions between Syrian women's practice of veiling in order to negotiate greater opportunities for access to work in a patriarchal context, and the less receptive position of 
western accounting firms to the hijab. This stresses the need to address embodiment in relation to socio-political, cultural and global conditions.

Another exception in addressing the gendered nature of embodiment in accounting is Haynes' (2008b) analysis of the relationship between the body and identity for women accounting professionals, especially in relation to pregnancy and early motherhood, where forms of embodiment can be seen simultaneously as a mechanism of social control, and as a form of self-expression and empowerment. Furthermore, Haynes (2012) argues that professions and professional services firms play a key role in defining a professional and gendered body image linked to their masculine history and cultural symbolism; this occurs through socialisation processes that contribute to the definition of the professional body, the role of the client in defining professionalism, the legitimation of certain types of embodied identities and the importance of the body in defining gendered perceptions of the self. Drawing on Bourdieu's concepts of capital, Haynes (2008b, 2012) demonstrates how embodied and gendered physical capital is implicated in processes of subordination and control in accounting in that categories and practices operate as material forces which help to shape and form women's and men's bodies in ways that reinforce particular images of femininity and masculinity. As with papers discussed earlier on identity and motherhood, there is a clear need to address both the gendered and gendering effects of embodiment in accounting, as 'there is a dialectical relationship between the body and the context in which it operates, each informing the other, such that the rules, hierarchies and metaphysical commitments of professional culture are inscribed on the body, and the body reflects this back' (Haynes, 2008, p. 343). Moreover, if models of embodiment based on one type of body, as the norm by which all others are judged, are to be refused, then there is ample scope for further work in accounting to expose the potential marginalisation or commodification of intersectional embodied identities. 


\subsection{Sexualities}

Although, as we have seen in this paper, gender encapsulates a range of behaviours, identities, masculinities and femininities in accounting, the issue of sex and sexuality is rarely addressed in relation to these, and where it is, it tends to be from a heterosexual perspective (Burrell, 1987, Rumens, 2015). Male heterosexual sexual cultures and female heterosexual countercultures, imbued with sexual symbolism derived from artefacts, images, language, behaviours and spaces, can entwine gendered power and domination, practice and resistance, in complex cultural codes and behaviours within accounting (Haynes, 2013b). Rumens (2015) laments the paucity of research on sexuality within accounting studies in general, and the lack of recognition of and research on lesbian, gay, bisexual and trans (LGBT) sexualities in particular. He offers a powerful argument for the use of queer theory to encourage new research into LGBT sexualities, laying down an explicit exhortation to critical accounting scholars to address a series of questions in future research to disrupt heteronormativity, address the queering of accounting organisations and go beyond a binary construction of sexuality (Rumens, 2015). Such a challenge reflects a wider need to address and articulate more inclusive identities in the professional accounting context.

\subsection{The gendering of men}

This need to encompass a range of gendered positions in critical accounting research on gender also relates to the gendering of men. Mostly (though not exclusively) the papers in this review have addressed the gendered position of women in accounting because women have traditionally been subjected to more oppressive social and cultural relations in the masculine professional context. However, just as women are not a unitary category, neither are men. Men also experience social and economic deprivation, poverty, violence, and exploitation 
under global capitalism. Men are equally subjected to the challenges within the accounting profession of long-working hours, masculine cultures, parenting, masculine embodiment, heteronormativity, and experience intersectional identities. To position men as a binary opposed to women in gender research ignores the complex nature of issues which relate to men and women alike: the reorganisation and precariousness of family and working life; the economic and cultural resources needed for the making of identity; and the commodification of emotional and intimate life under capitalism. Accounting's relationship with all of these areas is worthy of further study. This is not to argue for the reassertion of male dominance but the acknowledgement of male gendering in order to subvert and overturn gendered constructs.

\section{Feminist futures- critical accounting and gender going forward}

This review of critical research on gender and gendering in the accounting context has identified that there is a rich, valuable and varied body of work in this discipline, arising from many geographical and theoretical perspectives, addressing the gendered history of the profession and the contemporary gender challenges being enacted and experienced in its confines and in the name of accounting. The numbers and position of women in accounting has improved over the last 25 years, but challenges remain for both women and men at various levels where there is need for further research.

At the macro level of global capitalism we need to know more about the effects of the interaction of accounting and gender on the global stage, especially when accounting is used by nation states and societies as a tool to perpetuate power and control, and where consumers are far removed from the impacts of their actions on other peoples around the globe. We still know very little, for example, about the role of accounting in supporting war and human rights abuses at state and societal level, or the impact of accounting in perpetuating climate change 
and unsustainable business practices as they interlink with gender. At the meso level of the multi-national professional services firm, particularly given the globalised expansion of such firms, there is a need for further research on the construction of gender and its effects, through career structures and policies, gendered histories, identities, embodiments and behaviours, in a variety of global contexts. At the micro level of the individual, we also need to know more about the subjective experience of women and men subjected to gendered social constructions and constraints.

While we have seen recent calls for further work on exploring gendered cultural diversity in accounting (Komori, 2015), for widening gendered conceptualisations of accounting academia (Young, 2015) and for addressing LGBT sexualities in accounting (Rumens, 2015), there are other critical areas which have not been addressed in accounting literature. One such is sexual and gendered violence which can be addressed at the above three levels. Sexual violence can be understood as a social and cultural phenomenon, not only as a private phenomenon, that reveals and constructs gender and sexuality in many ways: at the state level through the use of rape as tool of war or through perpetuation by lack of state intervention and appropriate access to justice; at the community and organisational level, through human trafficking, prostitution and sexual commodification; and at the individual level through experience of rape and domestic violence. These issues may seem to be far removed from the confines and remit of accounting and accounting scholars, and no doubt they are difficult to research. However, as outlined earlier in this review, accounting is both a tool and political construct implicated in globalised capitalism through the pursuit of profit which underpins social and economic relationships. One might rightly ask therefore: what is the role of accounting in perpetuating sexual violence? 
Despite, or more appropriately because of, the post-feminist discourse permeating much of western society, in which 'equality' is perceived to have been achieved and the myth of 'choice' ignores social and cultural constraints, there remains a strong case for further feminist approaches to accounting research on gender. Moreover, in other non-western contexts feminism has found a new relevance (see, for example, Alsalloom, 2015). The role of a feminist perspective is to disrupt, subvert and emancipate from constraining gender norms. These norms will vary according to social and geographical context, but they share concerns over power and control; identity and difference. While there are many feminisms and feminist approaches to theory and praxis, contemporary transnationalist approaches (Mohanty, 2003) which address the interaction of gender, race, sexuality and class with economic exploitation under global capitalism would seem to hold high relevance for research in gender and accounting, given the previous argument about the role of accounting in perpetuating inequalities. This approach advances solidarity, mutuality and accountability in anti-colonial and anti-capitalist struggle, while recognising diversity and difference. Such feminist research on the interrelationship of gender and accounting could investigate the role, purpose and effect of accounting in interacting with globalised and localised contexts in which different forms of oppression and inequality are constituted, while also recognising the variety of alternative organisational and individual responses and forms of resistance aiming to create more justice and equality in the world, and providing insights into the further transformation of accounting's gendered and gendering role in our global society 


\section{Acknowledgements}

This research received no funding from any funding organisation.

\section{References}

Adapa S, Rindfleish J, Sheridan A. 'Doing Gender' in a Regional Context: Explaining Women's Absence from Senior Roles in Regional Accounting Firms in Australia. Critical Perspectives on Accounting. 2015; onlinefirst.

Almer ED, Lightbody MG, Single LE. Successful Promotion or Segregation from Partnership? An Examination of the "Post-Senior Manager" Position in Public Accounting and the Implications for Women's Careers. Accounting Forum. 2012;36:2, 122-33.

Alsalloom A. The Role of Women Accountants and the Implications for the Accounting Profession in Saudi Arabia. PhD Thesis. Southampton: Southampton University; 2015.

Alvesson M, Due Billing Y. Understanding Gender and Organizations. London: Sage; 1997.

Anderson-Gough F, Grey C, Robson K. 'Helping Them to Forget..':The Organizational Embedding of Gender Relations in Public Audit Firms. Accounting, Organizations and Society. 2005;30:5, 469-90.

Annisette M. Imperialism and the Professions: The Education and Certification of Accountants in Trinidad and Tobago. Accounting, Organizations and Society. 2000;25 631-59.

Annisette M. The Colour of Accountancy: Examining the Salience of Race in a Professionalisation Project. Accounting, Organizations and Society. 2003;28 639-74.

Benschop Y, Meihuizen HE. Keeping up Gendered Appearances: Representation of Gender in Financial Reports. Accounting, Organizations and Society. 2002;27 611 - 36.

Bernadi RA, Bean DF, Weippert KM. Signaling Gender Diversity through Annual Report Pictures: A Research Note on Image Management. Accounting, Auditing and Accountability Journal. 2002;15:4, $609-16$.

Bernadi RA, Bean DF, Weippert KM. Minority Membership on Boards of Directors: The Case for Requiring Pictures of Boards in Annual Reports. Critical Perspectives on Accounting. 2005;16:8, $1019-33$.

Bolton S, Muzio D. The Paradoxical Process of Feminization in the Professions: The Case of Established, Aspiring and Semi-Professions. Work, Employment and Society. 2008;22:2, 28199.

Bolton SC, Muzio D. Can't Live with 'Em; Can't Live without 'Em: Gendered Segmentation in the Legal Profession. Sociology. 2007;41:1, 47-64.

Broadbent J. The Gendered Nature of "Accounting Logic": Pointers to an Accounting That Encompasses Multiple Values. Critical Perspectives on Accounting. 1998;9:3, 267 - 97.

Broadbent J. Critical Accounting Research: A View from England. Critical Perspectives on Accounting. 2002;13:4, 433-49.

Broadbent J, Kirkham L. Glass Ceilings, Glass Cliffs or New Worlds? Accounting, Auditing and Accountability Journal. 2008;21:4, 465 - 73.

Bryer RA. The History of Accounting and the Transition to Capitalism in England. Part One: Theory. Accounting, Organizations and Society. 2000;25:2, 131-62.

Burrell G. No Accounting for Sexuality. Accounting, Organizations and Society. 1987;12:1, 89 - 101.

Carrera N, Gutierrez I, Carmona S. Gender, the State and the Audit Profession: Evidence from Spain (1942-88). European Accounting Review. 2001;10:4, 803-15.

Catchpowle L, Cooper C, Wright A. Capitalism, States and Ac-Counting. Critical Perspectives on Accounting. 2004; 15:8, 1037-58.

Chant S. Re-Thinking the "Feminization of Poverty" in Relation to Aggregate Gender Indices. Journal of Human Development. 2006;7:2, 201-20.

Chiapello E. Accounting and the Birth of the Notion of Capitalism. Critical Perspectives on Accounting. 2007;18:3, 263-96. 
Ciancanelli P, Gallhofer S, Humphrey C, Kirkham L. Gender and Accountancy: Some Evidence from the Uk. Critical Perspectives on Accounting. 1990;1:2, 117 - 44.

Cooper C. The Non and Nom of Accounting for (M)Other Nature. Accounting, Auditing and Accountability Journal. 1992;5:3, 16 - 39.

Cooper C. From Women's Liberation to Feminism: Reflections in Accounting Academia. Accounting Forum. 2001;25:3, 214 - 45.

Cooper C, Taylor P. From Taylorism to Ms. Taylor: The Transformation of the Accounting Craft. Accounting, Organizations and Society. 2000;25:6, 555 - 78.

Cooper DJ, Tinker T. Editorial Critical Perspectives on Accounting. 1990;1:1, 1-3.

Cooper K. Mary Addison Hamilton, Australia's First Lady of Numbers. Accounting History. 2008;13:2, 135-61.

Cooper K. Accounting by Women: Fear, Favour and the Path to Professional Recognition for Australian Women Accountants. Accounting History. 2010;15:3, 309-36.

Cregan K. The Sociology of the Body: Mapping the Abstraction of Embodiment. London: Sage; 2006.

Crompton R. Gender and Accountancy: A Response to Tinker and Neimark. Accounting, Organizations and Society. 1987;12:1, 103-10.

Dambrin C, Lambert C. Mothering or Auditing? The Case of Two Big Four in France. Accounting, Auditing and Accountability Journal. 2008;21:4, 474 - 506.

Dambrin C, Lambert C. Who Is She and Who Are We? A Reflexive Journey in Research into the Rarity of Women in the Highest Ranks of Accounting. Critical Perspectives on Accounting. 2012;23:1, 1 - 16.

Dillard J, Reynolds M. Green Owl and the Corn Maiden. Accounting, Auditing and Accountability Journal. 2008;21:4, 556 - 79.

Donovan J. Feminist Theory: The Intellectual Traditions. 3rd ed. New York: Continuum; 2001.

Duff A. Big Four Accounting Firms' Annual Reviews: A Photo Analysis of Gender and Race Portrayals. Critical Perspectives on Accounting. 2011;22:1, 20-38.

Duff A, Ferguson J. Disability and the Professional Accountant: Insights from Oral Histories. Accounting, Auditing and Accountability Journal. 2011a;25:1, 71 - 101.

Duff A, Ferguson J. Disability and the Socialization of Accounting Professionals Critical Perspectives on Accounting. 2011b;22:4, 351 - 64.

Edgley C, Sharma N, Anderson-Gough F. Diversity and Professionalism in the Big Four Firms: Expectation, Celebration and Weapon in the Battle for Talent. Critical Perspectives on Accounting. 2015; online first.

Fearfull A, Kamenou N. How Do You Account for It?: A Critical Exploration of Career Opportunities for and Experiences of Ethnic Minority Women. Critical Perspectives on Accounting. 2006;17:7, $883-901$.

Gallhofer S. M[Othering] View On : 'The Non and Nom of Accounting for (M)Other Nature'. Accounting, Auditing and Accountability Journal. 1992;5:3, 40-51.

Gallhofer S. The Silences of Mainstream Feminist Accounting Research. Critical Perspectives on Accounting. 1998;9:3, $355-75$.

Gallhofer S, Haslam J. Beyond Accounting: The Possibilities of Accounting and "Critical" Accounting Research. Critical Perspectives on Accounting. 1997;8:1-2, 71-95.

Gallhofer S, Paisey C, Roberts C, Tarbert H. What Has Changed? Reflections Upon Work-Life Balance among Female Scottish Chartered Accountants. Accounting, Auditing and Accountability Journal. 2011;24:4, 440 - 70.

Gammie E, Whiting R. Women Accountants: Is the Grass Greener Outside the Profession? British Accounting Review. 2013;45:2, 83-98.

Gendron Y, Spira L. Identity Narratives in Turmoil: A Study of Former Members of Arthur Andersen. Accounting, Organizations and Society. 2010;35:3, 275 - 300.

Grey C. On Being a Professional in a Big 6 Firm. Accounting, Organizations and Society. 1998;23:5/6, 569 - 87.

Hamilton SE. Exploring Professional Identity: The Perceptions of Chartered Accountant Students. The British Accounting Review. 2013;45:1, 37-49.

Hammond T. A White-Collar Profession: African American Certified Public Accountants since 1921. North Carolina: University Press; 2002. 
Hammond T. History from Accounting's Margins: International Research on Race and Gender. Accounting History. 2003;8:1, 9-24.

Hammond T, Oakes LS. Some Feminisms and Their Implications for Accounting Practice. Accounting, Auditing and Accountability Journal. 1992;5:3, 52 - 70.

Hammond T, Streeter D. Overcoming Barriers: Early African-American Certified Public Accountants. Accounting, Organizations and Society. 1994;19:3, 271 - 88.

Hammond TD. Sexual Harassment and the Public Accounting Industry: The Need for Critical Examination. Critical Perspectives on Accounting. 1997;8:3, 267 - 71.

Haynes K. Linking Narrative and Identity Construction: Using Autobiography in Accounting Research. Critical Perspectives on Accounting. 2006;17:4, 399 - 418.

Haynes K. Moving the Gender Agenda or Stirring Chicken's Entrails?: Where Next for Feminist Methodologies in Accounting? Accounting, Auditing and Accountability Journal. 2008a;21:4, 539 - 55.

Haynes K. (Re)Figuring Accounting and Maternal Bodies: The Gendered Embodiment of Accounting Professionals. Accounting, Organizations and Society. 2008b;33:4 - 5, 328 - 48.

Haynes K. Transforming Identities: Accounting Professionals and the Transition to Motherhood. Critical Perspectives on Accounting. 2008c;19:5, 620 - 42.

Haynes K. Tensions in (Re)Presenting the Self in Reflexive Autoethnographical Research. Qualitative Research in Organizations and Management. 2011;6:2, 134 - 49.

Haynes K. Body Beautiful?: Gender, Identity and the Body in Professional Services Firms. Gender, Work \& Organization. 2012;19:5, 489 - 507.

Haynes K. Gender and Diversity Challenges in Professional Services Firms. In: Haynes K, Grugulis I, editors. Managing Services: Challenges and Innovations. Oxford: Oxford University Press; 2013a. p. 66-82.

Haynes K. Sexuality and Sexual Symbolism as Processes of Gendered Identity Formation: An Autoethnography of an Accounting Firm. Accounting, Auditing and Accountability Journal. $2013 b ; 26: 3,374-98$.

Haynes K, Murray A. 'The Future Women Want' - Gender Equality and Sustainable Development: Towards an Agenda for Accounting Research. Asian-Pacific Interdisciplinary Perspectives on Accounting Conference. Kobe, Japan2013.

Haynes K, Murray A. Sustainability as a Lens to Explore Gender Equality: A Missed Opportunity for Responsible Management. In: Flynn PM, Haynes K, Kilgour MA, editors. Integrating Gender Equality into Management Education. Sheffield: Greenleaf; 2015.

Hines RD. Financial Accounting: In Communicating Reality, We Construct Reality. Accounting, Organizations and Society. 1988;13:3, 251 - 61.

Holvino E. Intersections: The Simultaneity of Race, Gender and Class in Organization Studies. Gender, Work \& Organization. 2010;17 248 - 77.

Hopwood A. Accounting and Gender: An Introduction. Accounting, Organizations and Society. 1987;12:1, $65-9$.

Ikin C, Johns L, Hayes C. Field, Capital and Habitus: An Oral History of Women in Accounting in Australia During World War Ii. Accounting History. 2012;17:2, 175-92.

IPCC. Fourth Assessment Report. Geneva: WMO/Intergovernmental Panel on Climate Change; 2007.

IPCC. Fifth Assessment Report. Geneva: WMO/Intergovernmental Panel on Climate Change; 2013.

Jacobs K. Class Reproduction in Professional Recruitment: Examining the Accounting Profession. Critical Perspectives on Accounting. 2003;14 569-96.

Jeacle I. Accounting and the Construction of the Standard Body. Accounting, Organizations and Society. 2003;28:4, 357 - 77.

Jeacle I. Face Facts: Accounting, Feminism and the Business of Beauty. Critical Perspectives on Accounting. 2006;17 87-108.

Jeacle I. Beyond the Boring Grey: The Construction of the Colourful Accountant. Critical Perspectives on Accounting. 2007;19:8, 1296-320.

Jeacle I. A Practice of Her Own: Female Career Success Beyond the Accounting Firm. Critical Perspectives on Accounting. 2011;22:3, 288 - 303.

Joyce Y, Walker SP. Gender Essentialism and Occupational Segregation in Insolvency Practice. Accounting, Organizations and Society. 2015;40:0, 41-60. 
Kamla R. Syrian Women Accountants' Attitudes and Experiences at Work in the Context of Globalization. Accounting, Organizations and Society. 2012;37:3, 188 - 205.

Kanter R. Men and Women of the Corporation: Basic Books; 1977.

Kelan EK. From Biological Clocks to Unspeakable Inequalities: The Intersectional Positioning of Young Professionals. British Journal of Management. 2014;25:4, 790-804.

Khalifa R. Intra-Professional Hierarchies: The Gendering of Accounting Specialisms in Uk Accountancy. Accounting, Auditing and Accountability Journal. 2013;26:8, 1212 - 45.

Kim SN. Imperialism without Empire: Silence in Contemporary Accounting Research on Race/Ethnicity. Critical Perspectives on Accounting. 2004;15:1, 95 - 133.

Kirkham L. Integrating Herstory and History in Accountancy. Accounting, Organizations and Society. 1992;17:3/4, 287 - 97.

Kirkham L, Loft A. Gender and the Construction of the Professional Accountant. Accounting, Organizations and Society. 1993;18:6, 507 - 58.

Kokot P. Structures and Relationships: Women Partners' Careers in Germany and the Uk. Accounting, Auditing and Accountability Journal. 2014;27:1, 48 - 72.

Kokot P. Let's Talk About Sex(Ism): Cross-National Perspectives on Women Partners' Narratives on Equality and Sexism at Work in Germany and the Uk. Critical Perspectives on Accounting. 2015;27:0, 73-85.

Komori N. The "Hidden" History of Accounting in Japan: A Historical Examination of the Relationship between Japanese Women and Accounting. Accounting History. 2007;12:3, 32958.

Komori N. Towards the Feminization of Accounting Practice: Lessons from the Experiences of Japanese Women in the Accounting Profession. Accounting, Auditing and Accountability Journal. 2008;21:4, 507-38.

Komori N. Beneath the Globalization Paradox: Towards the Sustainability of Cultural Diversity in Accounting Research. Critical Perspectives on Accounting. 2015;26:0, 141-56.

Kornberger M, Carter C, Ross-Smith A. Changing Gender Domination in a Big Four Accounting Firm: Flexibility, Performance and Client Service in Practice Accounting, Organizations and Society. 2010;35:8, 775 - 91.

Kornberger M, Justesen L, Mouritsen J. 'When You Make Manager, We Put a Big Mountain in Front of You': An Ethnography of Managers in a Big 4 Accounting Firm. Accounting, Organizations and Society. 2011;36:8, 514-33.

Kosmala K, Herrbach O. The Ambivalance of Professional Identity: On Cynicism and Jouissance in Audit Firms. Human Relations. 2006;59:10, 1393 - 428.

Kumra S. Exploring Career 'Choices' of Work-Centred Women in a Professional Service Firm. Gender in Management: an International Journal. 2010;25:3, 227-43.

Kumra S, Vinnicombe S. A Study of the Promotion to Partner Process in a Professional Services Firm: How Women Are Disadvantaged. British Journal of Management. 2008;S1:19, S65 S74.

Kumra S, Vinnicombe S. Impressing for Success: A Gendered Analysis of a Key Social Capital Accumulation Strategy. Gender, Work \& Organization. 2010;17:5, 521 - 46.

Kyriacou O. Accounting for Images of 'Equality' in Digital Space: Towards an Exploration of the Greek Accounting Professional Institute. Critical Perspectives on Accounting. 2015;online first.

Ladva P, Andrew J. Weaving a Web of Control: "The Promise of Opportunity" and Work-Life Balance in Multinational Accounting Firms. Accounting, Auditing and Accountability Journal. 2014;27:4, 634 - 54.

Larson M. The Rise of Professionalism: A Sociological Analysis. Berkeley, California: University of California Press; 1977.

Lee Cooke F, Xiao Y. Gender Roles and Organizational Hr Practices: The Case of Women's Careers in Accountancy and Consultancy Firms in China. Human Resource Management. 2014;53:1, 23-44.

Lehman C. 'Herstory' in Accounting: The First Eighty Years. Accounting, Organizations and Society. 1992;17:3-4, 261-85. 
Lehman C. We've Come a Long Way! Maybe! Re-Imagining Gender and Accounting. Accounting, Auditing and Accountability Journal. 2012;25:2, 256 - 94.

Lewis P. Postfeminism, Femininities and Organization Studies: Exploring a New Agenda. Organization Studies. 2014.

Loft A. Accountancy and the Gendered Division of Labour: A Review Essay. Accounting, Organizations and Society. 1992;17:3/4, 367 - 78.

Lupu I. Approved Routes and Alternative Paths: The Construction of Women's Careers in Large Accounting Firms. Evidence from the French Big Four. Critical Perspectives on Accounting. 2012;23:4-5, 351-69.

Lyonette C, Crompton R. The Only Way Is Up? An Examination of Women's 'under-Achievement' in the Accountancy Profession in the Uk. Gender in management: an international journal. 2008;23:7, 506-21.

MacDonald K. The Sociology of the Professions. London: Sage; 1995.

McNicholas P, Humphries M, Gallhofer S. Maintaining the Empire: Maori Women's Experiences in the Accountancy Profession. Critical perspectives on accounting. 2004;15 57-93.

McRobbie A. Post-Feminism and Popular Culture. Feminist Media Studies. 2004;4:3, 255-64.

McRobbie A. The Aftermath of Feminism: Gender, Culture and Social Change. Los Angeles \& London: Sage; 2009.

Mohanty CT. Feminism without Borders: Decolonizing Theory, Practicing Solidarity. Durham and London: Duke University Press; 2003.

Morales J, Gendron Y, Guénin-Paracini H. State Privatization and the Unrelenting Expansion of Neoliberalism: The Case of the Greek Financial Crisis. Critical Perspectives on Accounting. 2014;25:6, 423-45.

Morales J, Lambert C. Dirty Work and the Construction of Identity. An Ethnographic Study of Management Accounting Practices. Accounting, Organizations and Society. 2013;38:3, 22844.

Mueller F, Carter C, Ross-Smith A. Making Sense of Career in a Big Four Accounting Firm. Current Sociology. 2010;59:4, 551 - 67.

Nemoto K. When Culture Resists Progress: Masculine Organizational Culture and Its Impacts on the Vertical Segregation of Women in Japanese Companies. Work, Employment and Society. 2013;27:1, 153-69.

Nichols D, Robinson RK, Reithel BJ, Franklin GM. An Exploratory Study of Sexual Behavior in Accounting Firms: Do Male and Female Cpa's Interpret Sexual Harassment Differently? Critical Perspectives on Accounting. 1997;8:3, 249 - 64.

Oakley A. Sex, Gender and Society. 2nd ed. Aldershot: Gower Publishing; 1985.

Parker LD, Guthrie J. Addressing Directions in Interdisciplinary Accounting Research. Accounting, Auditing and Accountability Journal. 2014;27:8, 1218-26.

Roberts J, Coutts JA. Feminization and Professionalization: A Review of an Emerging Literature on the Development of Accounting in the United Kingdom. Accounting, Organizations and Society. 1992;17:3/4, 379-95.

Robinson-Backman I, Weisenfeld L. An Investigation of Perceived Discrimination and Career Advancement Curtailment: The African-American Female Accountant's Perspective. Advances in Public Interest Accounting. 2001;8 241 - 75.

Rumens N. Sexualities and Accounting: A Queer Theory Perspective. Critical Perspectives on Accounting. 2015; online first.

Shackleton K. Gender Segregation in Scottish Chartered Accountancy: The Deployment of Male Concerns About the Admission of Women, 1900 - 25. Accounting, Business and Financial History. 1999;9:1, 135 - 56.

Shearer TL, Arrington CE. Accounting in Other Wor(L)Ds: A Feminism without Reserve. Accounting, Organizations and Society. 1993;18:2/3, 253 - 72.

Shilling C. The Body and Social Theory. London: Sage; 1993.

Spence C, Dambrin C, Carter C, Husillos J, Archel P. Global Ends, Local Means: Cross-National Homogeneity in Professional Service Firms. Human Relations. 2015;68:5, 765-88.

Turner B. Body and Society. London: Sage; 1996. 
United Nations. Millennium Development Goals Report: Gender Chart. New York: United Nations; 2012.

United Nations Department of Economic and Social Affairs. The World's Women. New York: United Nations; 2010.

United Nations Economic Commission for Africa. Gender and Climate Change - Women Matter. United Nations; 2009.

Viator RE. An Examination of African American's Access to Public Accounting Mentors: Perceived Barriers and Intentions to Leave. Accounting, Organizations and Society. 2001;26 541-61.

Walker SP. Identifying the Woman Behind the "Railed-in Desk". Accounting, Auditing and Accountability Journal. 2003a;16:4, 606 - 39.

Walker SP. Professionalisation or Incarceration? Household Engineering, Accounting and the Domestic Ideal. Accounting, Organizations and Society. 2003b;28:7/8, 743 - 72.

Walker SP. Accounting Histories of Women: Beyond Recovery? Accounting, Auditing and Accountability Journal. 2008;21:4, 580 - 610.

Walker SP. Ethel Ayres Purdie: Critical Practitioner and Suffragist. Critical Perspectives on Accounting. 2011a;22 79-101.

Walker SP. Professions and Patriarchy Revisited: Accountancy in England and Wales, 1887-1914. Accounting History Review. 2011b;21:2, 185 - 225.

Westcott SH, Seiler RE. Women in the Accounting Profession. New York: Marcus Weiner; 1986.

Whiting RH, Wright $\mathrm{C}$. Explaining Gender Inequity in the New Zealand Accountng Profession. The British Accounting Review. 2001;33:2, 191-222.

Windsor C, Auyeung P. The Effect of Gender and Dependent Children on Professional Accountants' Career Progression. Critical Perspectives on Accounting. 2006;17:6, 828 - 44.

Wootton C, Kemmerer B. The Changing Genderization of Bookkeeping in the United States, 1870 1930. Business History Review. 1996;70:4, 541 - 86.

Wootton C, Kemmerer B. The Changing Genderization of the Accounting Workforce in the Us, 193090. Accounting, Business and Financial History. 2000;10:2, 169 - 90.

Young JJ. (En)Gendering Sustainability. Critical Perspectives on Accounting. 2015;26:0, 67-75. 